(2) OPEN ACCESS

\title{
War journalism: an occupational exposure
}

\author{
Nicola Magnavita, ${ }^{1,2}$ Maria Teresa Congedo, ${ }^{3}$ Reparata Rosa Di Prinzio, ${ }^{1,2}$ \\ Angela Iuliano ${ }^{1,2}$
}

'Postgraduate School of

Occupational Health, Università Cattolica del Sacro Cuore Facoltà di Medicina e Chirurgia, Rome, Lazio, Italy

${ }^{2}$ Department of Woman, Child and Public Health, Fondazione Policlinico Universitario Agostino Gemelli IRCCS, Rome, Lazio, Italy

${ }^{3}$ Department of Medical and Surgical Sciences, Operational Unit of Thoracic Surgery, Fondazione Policlinico Universitario Agostino Gemelli IRCCS, Rome, Lazio, Italy

Correspondence to

Dr Reparata Rosa Di Prinzio; repdip@gmail.com

Accepted 23 September 2021

Check for updates

(c) BMJ Publishing Group Limited 2021. Re-use permitted under CC BY-NC. No commercial re-use. See rights and permissions. Published by BMJ.

To cite: Magnavita $\mathrm{N}$, Congedo MT,

Di Prinzio RR, et al. BMJ Case Rep 2021:14:e245165. doi:10.1136/bcr-2021. 245165

\section{SUMMARY}

Apart from the risk of accidents, war theatres present a hazard related to numerous long-lasting toxic agents. For 10 years, a $>60$-year-old male journalist worked in war theatres in the Far and Near East where he was exposed to asbestos and other toxic substances (metals, silica, clays, polycyclic aromatic hydrocarbons and other organic substances) contained in dust and smoke of destroyed buildings. More than 15 years later, he developed a mucoepidermoid carcinoma of the soft palate and, subsequently, a pleural malignant mesothelioma. The safety of war journalists should focus not only on preventing the risk of being killed, but also on providing protection from toxic and carcinogenic agents. Exposure to substances released during the destruction of buildings can also pose a carcinogenic risk for survivors.

\section{BACKGROUND}

In our modern society based largely on images, there is mounting pressure on reporters to transmit breaking news in real time from the places where important events are taking place. Journalists are required to intervene as soon as possible in war theatres to report attacks, destruction and devastation. War journalism has always been associated with heroic figures who risk their lives, but in war theatres there is an added risk related to numerous toxic agents whose long-lasting action leads to chronic disabling effects on health. These include, for example, carcinogenic agents such as Agent Orange, a mixture of phenoxy herbicides containing traces of tetrachlorodibenzo-p-dioxin, that was widely used in Vietnam, ${ }^{1}$ depleted uranium (DU) used in munitions and associated with the Gulf War Syndrome, ${ }^{2}$ and asbestos fibres resulting from the destruction of buildings. ${ }^{3}$ All of these substances have been associated with adverse effects on the military as well as on refugees and survivors. There is still a lack of knowledge concerning these risks and no measures of prevention have been undertaken. Therefore, war journalists are unavoidably and unwittingly exposed to heavily polluted environments.

\section{CASE PRESENTATION}

In February 2021, a >60-year-old male journalist was hospitalised for a massive right pneumothorax. He was a social drinker with a physically active lifestyle. At a young age he had been a heavy smoker (from 25 to 50 years of age, more than 20 cigarettes a day, 35 packs/year before quitting smoking) and had subsequently developed emphysematous chronic bronchitis. Starting from the early 1990s, he had worked as a war correspondent in the
Balkans, Iraq and Afghanistan for about 10 years. Since 2003, he had been working in an urban office. Family history was positive for cancers which affected both parents (lung cancer) and two sisters (breast cancer).

When questioned about his war experience, he stated that during each mission he had lived for many months among the rubble of bombed-out buildings, constructed mainly in the 1950 s and 1960 s with the extensive use of asbestos. The destruction of entire urban and industrial areas had created mountains of rubble where everything was covered in dust, and it was impossible to avoid breathing it. Referring to himself and his colleagues he is reported as saying, 'At times we felt like we were chewing that air, it was so thick and slimy'.

In 2017 he developed a mucoepidermoid carcinoma (MEC) of the soft palate and underwent surgery (partial maxillectomy and palate reconstruction). The diagnosis was confirmed by histochemical methods (diffuse p63, CK19 and CK14 phenotype, focally positive for Cam 5.2).

During the recent hospitalisation, after pleural drainage, persistent air loss and incomplete pulmonary re-expansion, a thoracoscopy and biopsies were performed. A multifocal malignant pleural mesothelioma (MM) with microfoci of initial infiltration was diagnosed. The patient underwent surgery (right apicoectomy for bullous dystrophy and chemical pleurodesis) and chemotherapeutic treatment (cisplatin and pemetrexed).

\section{GLOBAL HEALTH PROBLEM LIST}

The presence of two neoplasms of the respiratory tract in the same subject requires evaluating whether an environmental agent could be responsible for both, and whether this agent was present in the patient's workplace.

\section{GLOBAL HEALTH PROBLEM ANALYSIS}

Current knowledge on carcinogenesis suggests that the combined presence of both a germline genetic variant and a known environmental factor can modulate the risk of cancers more than either one alone. For example, the inherited loss-of-function mutations in the BAP1 onco-suppressor gene predispose to $\mathrm{MM}$ in asbestos-exposed individuals and other cancers ${ }^{4}$ including MEC in non-exposed patients. ${ }^{5}$ Therefore, there may also be a genetic link between the two types of neoplasia. The patient had a marked neoplastic familiarity, and this leads to the suspicion of a genetic predisposition. The fact that the neoplastic diseases manifested themselves more than 15 years after the patient's activity in war 
zones, led us to consider exposure to agents that act over periods of long latency.

First, we took into account fumes, dust and fibres resulting from the destruction of buildings. As the attack on the Twin Towers demonstrated, large quantities of dust are dispersed into the air, including very small particles $(2.5 \mu \mathrm{m})$ belonging to the so-called respirable fraction. Such particles can penetrate the alveoli and are composed of an alkaline mixture of crushed concrete, gypsum, silica and fibres that is extremely harmful for the respiratory system. ${ }^{6}$ Silica dust exposure is associated with an increased risk of laryngeal and lung cancer in workers who had already developed silicosis, ${ }^{78}$ although there is little evidence of the carcinogenic role of silica per se in the absence of silicosis. ${ }^{8}$ On the contrary, asbestos fibres exert a carcinogenic effect even in the absence of pneumoconiosis, ${ }^{9}$ and have been associated with single exposure to a household or neighbourhood/ community asbestos source. ${ }^{10}$ Asbestos released into the air was a significant risk factor for workers engaged in debris removal after the destruction of the World Trade Center (WTC) in New York City (NYC) on 11 September 2001. ${ }^{11}$ It is acknowledged that 1 fibre/mL per year of asbestos is sufficient to significantly increase the risk of $\mathrm{MM} .^{12}$ The exposure of the patient in this case report might have been significantly worse than that experienced by workers engaged in removal of rubble at the WTC, considering both the great quantity of asbestos fibres and the long duration of exposure. In fact, large quantities of asbestos and asbestos-cement are used in the construction of buildings in Balkan and Asian countries. Previous evidence has shown that exposure to dust produced by collapsing buildings has inflammatory and cytotoxic effects on the pulmonary endothelium, ${ }^{13}$ and long-term exposure to asbestos fibres is the main aetiological cause of MM. ${ }^{14}$ A possible role of asbestos exposure has been hypothesised in a case of MEC. ${ }^{15}$

The patient also reported that several colleagues suffered from the Balkan syndrome, a complex chronic illness characterised by disorders mainly affecting the haematopoietic system and associated with exposure to DU, chemicals, desert dust, biological agents and vaccines. ${ }^{16}$ This syndrome has also been observed in soldiers deployed in Bosnia-Herzegovina and Kosovo in the late 1990s. The latter were exposed to North Atlantic Treaty Organization antitank missiles and bombs containing DU that might be linked to the development of neoplasms. ${ }^{17}$ However, a review of studies performed in Gulf War and Balkan veterans did not give consistent evidence of excess risks of neoplasms possibly related to exposure to $\mathrm{DU}^{18}$ and more recent studies on veterans deployed in Bosnia-Herzegovina and Kosovo did not show any increase in general mortality or in cancer. ${ }^{19}$ In the described case, the main carcinogens to which the workers had been exposed were silica and asbestos. Silica dust, or silicon dioxide, is commonly found in nature in crystalline form as quartz or cristobalite, as well as in amorphous form; both are contained in concrete. Crystalline silica is included in the International Agency for Research on Cancer Group 1 agents carcinogenic to humans, while amorphous silica is included in the Group 3, not classifiable as to its carcinogenicity to humans. ${ }^{9}$ Asbestos in all forms, including actinolite, amosite, anthophyllite, chrysotile, crocidolite and tremolite is included in Group 1 of human carcinogens, ${ }^{9}$ with a latency of induced MM that can be up to 50 years. The time elapsed from exposure in this patient was likely sufficient for the induction of neoplastic effects.

When evaluating occupational exposure as a cause of illness, it is necessary to take into account the habit of smoking. A recent meta-analysis confirms that tobacco smoke has an additive interaction with asbestos exposure in the genesis of lung cancer, ${ }^{20}$ and it can be assumed that the same is true for soft palate neoplasia. Conversely, it is well known that smoking has no relationship with $\mathrm{MM}^{21}$

This case report has some weaknesses. The main one, from the point of view of occupational health, is the lack of data on the type of pollutants present in war theatres and their levels. The observations made after the WTC disaster ${ }^{22}$ certainly differ from the conditions that occur in other countries; however, they indicate the harmfulness of demolition products. Another limitation is the lack of genetic tests on the worker, which could have verified the hypothesis of a genetic predisposition to cancer that is suggested by the familiarity.

For the protection of subjects who work in areas in which, following demolitions, there is pollution from asbestos fibres and silica particles, respiratory personal protective equipment (namely, filtering face masks able to filter 99\% of airborne particles) and decontamination of clothing are measures whose effectiveness has been proven over many decades of experience in air polluted workplaces. ${ }^{23}$

In conclusion, this case underlines the need for a thorough assessment of the occupational hazards and risks for all workers engaged in war scenarios. Personal protective equipment should be supplied to reduce pathological health effects to a minimum. Moreover, regular check-ups should be introduced to provide early diagnosis and treatment.

This topic has a significant impact on public health because exposure to debris affects not only the military and professionals in the field, but also the civilian population. To date, the problem of cancer in refugees, displaced populations and war survivors has been posed exclusively from the point of view of the need for resources to diagnose and treat the disease, ${ }^{24}$ but it has not been considered from a prevention perspective. Unfortunately, no long-term studies are available on the incidence of MM or other cancers in the population residing in conflict areas; however, studies in refugees observed that median age of onset of cancer was significantly lower, and disease progression was significantly

\section{Patient's perspective}

The work of journalists reporting events in areas of crisis has been influenced by changes in the global geopolitical scene that has moved regional conflict theatres from developing countries to geographic areas closer to the industrialised world and to the very heart of Europe.

Safety provisions for reporters have also been affected by changes in the geographical boundaries of regional conflicts: protective equipment adopted prior to those changes (eg, splinter and bulletproof vests, Kevlar helmets and armoured cars) is useless against the invisible and more insidious risks related to toxic or poisonous agents and radioactive or carcinogenic materials. None of the thousands of reporters who spent long periods in areas of conflict were aware of the dangers of being exposed to such risks that are just as hazardous as those posed by conventional weapons.

Following extensive bombing, the areas in which we operated were reduced to rubble and the air we breathed was full of dust from collapsed buildings. Had we been aware of the risks involved, we could have taken preventive measures such as adopting air filtering devices. Since this did not occur, there is a very real fear that because of unwitting exposure to toxic chemical/physical agents, many of us will manifest symptoms of a serious disease in the near future. 
Learning points

- Several agents that can induce neoplasms of the respiratory system are present in war theatres.

- Journalists working in war theatres are exposed to asbestos, depleted uranium and other carcinogens.

- Therefore, the safety of war journalists should focus not only on preventing the risk of being killed, but also on providing protection from toxic and carcinogenic agents.

more frequent in refugees than in the host population. ${ }^{25}$ This finding could be related to toxic exposure during the conflict. Studies on populations exposed to asbestos pollution in underdeveloped countries, where misinformation and social inequities dominate, are also very limited; however, in these areas the few epidemiological studies available show clear evidence of clusters of $\mathrm{MM}$ in association with environmental asbestos exposure. ${ }^{26}$ Recent studies have shown that WTC survivors, that is, the population of local residents and workers present in the NYC disaster area on 11 September 2001 or in the days or weeks following, developed MM and other rare neoplasms. ${ }^{27}$ War reporters are therefore only the tip of the iceberg. The harm caused by war destruction is much more serious and persistent than the damage that is immediately visible.

Acknowledgements We thank Dr Gabriele Arnesano and Dr Igor Mauro for participating to the bibliographical data research. We are grateful to Ms EA Wright for the language editing of the manuscript.

Contributors NM conceived and revised the paper. MTC provided clinical data of the subject and revised the paper. RRDP and Al analysed data and drafted the paper

Funding The authors have not declared a specific grant for this research from any funding agency in the public, commercial or not-for-profit sectors.

\section{Competing interests None declared.}

Patient consent for publication Consent obtained directly from patient(s). Provenance and peer review Not commissioned; externally peer reviewed.

Open access This is an open access article distributed in accordance with the Creative Commons Attribution Non Commercial (CC BY-NC 4.0) license, which permits others to distribute, remix, adapt, build upon this work non-commercially, and license their derivative works on different terms, provided the original work is properly cited and the use is non-commercial. See: http://creativecommons.org/ licenses/by-nc/4.0/.

\section{REFERENCES}

1 National Academies of Sciences, Engineering, and Medicine; Health and Medicine Division; Board on Population Health and Public Health Practice; Committee to Review the Health Effects in Vietnam Veterans of Exposure to Herbicides (Eleventh Biennial Update). Veterans and agent orange: update 11 (2018. Washington (DC): National Academies Press (US), 2018.

2 Bjørklund G, Pivina L, Dadar M, et al. Depleted uranium and Gulf War illness: updates and comments on possible mechanisms behind the syndrome. Environ Res 2020;181:108927.
3 Hoskins JA, Brown RC. Contamination of the air with mineral fibers following the explosive destruction of buildings and fire. Drug Metab Rev 1994;26:663-73.

4 Testa JR, Cheung M, Pei J, et al. Germline BAP1 mutations predispose to malignant mesothelioma. Nat Genet 2011:43:1022-5.

5 Betti M, Casalone E, Ferrante D, et al. Inference on germline BAP1 mutations and asbestos exposure from the analysis of familial and sporadic mesothelioma in a highrisk area. Genes Chromosomes Cancer 2015;54:51-62.

6 Lippmann M, Cohen MD, Chen L-C. Health effects of World Trade center (WTC) dust: an unprecedented disaster's inadequate risk management. Crit Rev Toxicol 2015:45:492-530

7 Chen M, Tse LA. Laryngeal cancer and silica dust exposure: a systematic review and meta-analysis. Am J Ind Med 2012:55:669-76.

8 Pelucchi C, Pira E, Piolatto G, et al. Occupational silica exposure and lung cancer risk: a review of epidemiological studies 1996-2005. Ann Oncol 2006;17:1039-50.

9 IARC. IARC Monographs on the evaluation of carcinogenic risks to humans volume 14, sup. 7, 100C. Arsenic, metals, fibres, and dusts, 2012. https://publications.iarc.fr/ 120

10 Marchevsky AM, Harber P, Crawford L, et al. Mesothelioma in patients with nonoccupational asbestos exposure. an evidence-based approach to causation assessment. Ann Diagn Pathol 2006;10:241-50.

11 Geyh AS, Chillrud S, Williams D'Ann L, et al. Assessing truck driver exposure at the world Trade center disaster site: personal and area monitoring for particulate matter and volatile organic compounds during October 2001 and April 2002. J Occup Environ Hyg 2005;2:179-93

12 Markowitz S. Asbestos-related lung cancer and malignant mesothelioma of the pleura: selected current issues. Semin Respir Crit Care Med 2015;36:334-46.

13 Hernandez M, Harrington A, Ma Y, et al. World Trade center dust induces airway inflammation while promoting aortic endothelial dysfunction. Toxicol Appl Pharmacol 2020;400:115041.

14 Attanoos RL, Churg A, Galateau-Salle F, et al. Malignant mesothelioma and its nonasbestos causes. Arch Pathol Lab Med 2018;142:753-60.

15 Markotic A. Balkan syndrome. Lancet 2002;359:166.

16 Abdalla M, Sinyagovskiy P, Mohamed W, et al. A rare case of pulmonary mucoepidermoid carcinoma in an 81-year-old male. Am J Case Rep 2018;19:1499-502.

17 Duraković A. On depleted uranium: gulf war and Balkan syndrome. Croat Med J 2001:42:130-4.

18 Lagorio S, Grande E, Martina L. [Review of epidemiological studies of cancer risk among GulfWar and Balkans veterans]. Epidemiol Prev 2008;32:145-55.

19 Capocaccia R, Biselli R, Ruggeri R, et al. Mortality in Italian veterans deployed in Bosnia-Herzegovina and Kosovo. Eur J Public Health 2016;26:712-7.

20 Ngamwong Y, Tangamornsuksan W, Lohitnavy 0 , et al. Additive synergism between asbestos and smoking in lung cancer risk: a systematic review and meta-analysis. PLoS One 2015:10:e0135798.

21 Muscat JE, Wynder EL. Cigarette smoking, asbestos exposure, and malignant mesothelioma. Cancer Res 1991:51:2263-7.

22 Lioy PJ, Weisel CP, Millette JR, et al. Characterization of the dust/smoke aerosol that settled East of the world Trade center (WTC) in lower Manhattan after the collapse of the WTC 11 September 2001. Environ Health Perspect 2002;110:703-14.

23 Brown SK. Asbestos exposure during renovation and demolition of asbestos-cement clad buildings. Am Ind Hyg Assoc J 1987;48:478-86.

24 Spiegel PB, Cheaib JG, Aziz SA, et al. Cancer in Syrian refugees in Jordan and Lebanon between 2015 and 2017. Lancet Oncol 2020;21:e280-91.

25 Yağcı-Küpeli B, Özkan A. Syrian and Turkish children with cancer: a comparison on survival and associated factors. Pediatr Hematol Oncol 2020;37:707-16.

26 Algranti E, Ramos-Bonilla JP, Terracini B, et al. Prevention of asbestos exposure in Latin America within a global public health perspective. Ann Glob Health 2019;85:49.

27 Durmus N, Shao Y, Arslan AA, et al. Characteristics of cancer patients in the world Trade center environmental health center. Int I Environ Res Public Health 2020;17:7190 


\section{Global health}

Copyright 2021 BMJ Publishing Group. All rights reserved. For permission to reuse any of this content visit https://www.bmj.com/company/products-services/rights-and-licensing/permissions/

BMJ Case Report Fellows may re-use this article for personal use and teaching without any further permission.

Become a Fellow of BMJ Case Reports today and you can:

- Submit as many cases as you like

- Enjoy fast sympathetic peer review and rapid publication of accepted articles

- Access all the published articles

Re-use any of the published material for personal use and teaching without further permission

Customer Service

If you have any further queries about your subscription, please contact our customer services team on +44 (0) 2071111105 or via email at support@bmj.com.

Visit casereports.bmj.com for more articles like this and to become a Fellow 